\title{
Heidegger's Absolute Music, or What Are Poets for When the End of Metaphysics Is At Hand?
}

\author{
JOHN LYSAKER
}

University of Oregon

\begin{abstract}
A poem telling the story of a man shooting a moose is a narrative poem.

If the poem goes on for a long time and the moose turns out to be his daughter who got screwed by the lecherous, jealous gods and the man then founds a city, it is an epic.

Many say the Age of the Epic is behind us, the rain falls upon the moose corpse and the murderous, capricious gods seem done with us, killed or wandered off, and, unattended, unhouselled, we charge through the bracken with only the burning hoof print of human love upon us.
\end{abstract}

—Dean Young, "The Decoration Committee," lines 1-131

What does it mean to begin with and from the claim that "the end of metaphysics is at hand"? Undoubtedly, multiple things, but I want to focus on issues involving the phrase "at hand" and the nature of the "claim," leaving aside the meaning of this "end" and "metaphysics." First, ours is a century full of claims concerning the end of metaphysics. In that sense, the claim is "at hand" in 
being readily available. From Carnap to Rorty, Horkheimer to Habermas, from Heidegger to Derrida, traditions have gathered around the claim that metaphysics has come to its end. The form of this availability bears notice, however. As a claim, it is an assertion: "metaphysics is at its end." And in its wake, one expects arguments, arguments which support the assertion and ask that we support it as well.

The "end of metaphysics" is something more than an assertion, however. Ours is a time when philosophers of diverse sensibilities cry out that metaphysics is at its end. In the tradition of Carnap and Rorty, metaphysics has drawn to an end given the triumph of naturalism, even if that triumph can only claim a pragmatic (which is not to say pyrrhic) victory. Among the critical theorists, metaphysics, as a grounding discourse, has been superseded by a critical theory whose reconstructive engine is fueled by the social sciences. And beginning with Heidegger, the end of metaphysics names a kind of exhaustion, as if the path of inquiry opened by the question "what is the nature of $\mathrm{X}$ " had reached a limit, one that metaphysics undoubtedly engages but cannot render transparent. Quite a range. It seems, therefore, that the end of metaphysics is both a social phenomenon and an assertion. Perhaps we should approach the former from the etymological roots of "claim," i.e., clamare, "to cry out," for many do cry out that metaphysics has come to an end. And yet, this is far from a univocal choir. The voices crying out are diverse to the point of incompatibility. We might do better, then, to pursue the matter through another descendent of clamare, i.e., "clamor," for beginning with the claim "the end of metaphysics is at hand" throws us into an uproar.

Another orienting thought. In the Lowell lectures of 1906, William James writes of the pragmatist theory of truth: "I fully expect to see the pragmatist view of truth run through the classic stages of a theory's career. First, you know, a new theory is attacked as absurd; then it is admitted to be true, but obvious and insignificant; finally it is seen to be so important that its adversaries claim that they themselves discovered it." ${ }^{\prime 2}$ Concerning claims pertaining to the end of metaphysics, I believe we are arriving at the end of stage two. Many, like Rorty, consider the claim banal. ${ }^{3}$ We all know, he claims, that the heyday of metaphysics is over, so let us get on with something more interesting, if not more useful. But I want to pause in this banality, and note it, suggesting that for some "the end of metaphysics is at hand" is like a light switch, a matter of course; one flicks it on in order to get on with some other task.

For a third thought, let us return to the idea of a "claim." Many, I claimed, assert that metaphysics has come to its end. If we begin with and from the claim that "the end of metaphysics is at hand," we do so within the figure of thought that Heidegger terms an "assertion," an Aussatz. This is significant, for on Heidegger's reading, the assertion prevents philosophy from recognizing the end of metaphysics. Why? The assertion, schematized as " $X$ is $y$," is not only 
"not the primary locus (Ort) of truth," something Heidegger notes in Sein und Zeit, $\S 44$, but is bound to Insistenz, to the errancy that Heidegger regards as a "dogged sticking to what exists, to what is offered by beings as if they were open in and of themselves." More specifically, the assertion (or the proposition), in ascribing a predicate to a being, regards the being of this $\mathrm{X}$ in terms of what is present in the form of essential traits, or speaking retroactively, as empirical sciences do, in terms of those traits that can be said to endure through a series of transformations. In so comporting ourselves towards $\mathrm{X}$, we forget, however, to interrogate the event of X's and our presencing, and thus overlook the Ort, the locus of disclosure. Now such forgetfulness defines for Heidegger the history of metaphysics as a kind of nihilism, for it thinks Sein only in terms of das Seiende, as we do when asserting things, when predicating y of $\mathrm{X}$. If we ask then "what does it mean to begin with and from the claim that the end of metaphysics is at hand," we might conclude that this beginning already falls back into metaphysics. Or, more humbly, we could "suggest" that to begin with such a claim is to have only just begun, that is, we could "claim" that such a claim opens the question of the end of metaphysics rather than answers it. In this regard, the regard of the claim, the end of metaphysics would be at hand only in a deferred sense, as something yet to be fathomed.

I want to draw one more preliminary thought from the notion of the claim, if only to quiet the clamor of the day, scratch the banality of what is at hand until it fades into strangeness, and heed Heidegger's worries concerning the limits of propositional thinking. Bracket, if you will, our tendencies to associate claims with assertions, and consider a lead from Webster's second edition. There we are told that a claim is a "demand for something rightfully or allegedly due." With this definition in mind, we might regard a philosophical claim as an apologia on behalf of some matter to be thought, as a demand that some Sache be recognized. If so, beginning with and from the claim that the end of metaphysics is at hand could initiate a practice of bearing witness to a matter that demands recognition. Having begun so, we could then declare, or rather cry out, that the "end of metaphysics is at hand," emphasizing that we are working amidst an event "still on its way," to recall Nietzsche's announcement of the death of god. And thus we might leave this exhortation with an admission: as is evident from the clamor it has provoked, the end of metaphysics, as an event, has laid claim to our age, and if we make claims on its behalf, we do so with an awareness that we may need help from quarters not governed by assertions.

\section{Heidegger's Ear}

He made a line on the blackboard, one bold stroke from right to left diagonally downward and stood back to ask, looking at no one 
in particular, "What have I done?"

From the back of the room Freddie

shouted, "You've broken a piece

of chalk." M. Degas did not smile.

"What have I done?" he repeated.

- Philip Levine, "M. Degas Teaches Art \& Science At Durfee Intermediate School Detroit, 1942," lines 1-95

In 1946, amidst the nihilism that he found characteristic of metaphysics, a nihilism that he aligned with the spread of modern technology as a mode of disclosure grounded in forgetfulness, Heidegger asked "Wozu Dichter [What are poets for?]" and proceeded to explore the work of Rilke. A few years earlier, in 1942, he had invoked Hölderlin against the onslaught of America, whose entry into World War II he described as "the ultimate act of American ahistoricality and self-devastation" (GA 53: 68; DI, 54-5). And still earlier, in 1934, when the engines of death had begun to solidify their hold on the future of the European Jewry, Heidegger had also turned to Hölderlin for direction, claiming that the "poet is the grounder of being," adding that the poetic is "the fundamental happening [Grundgeschehen] of the historical dasein of human beings" (GA 39: 33, 36). But "direction" skews the matter, for when Heidegger turned to Hölderlin in 1934, it was not for adornment or the lyric presentation of an encrypted philosophical project. In fact, he warned against such approaches, writing that: "The danger exists, that we [will] set the poetic work within concepts, that we only [will] comb a poem for the philosophical opinions and tenets of the poet, that we [will] piece together Hölderlin's philosophical system and explain the poetry from such an account" (GA 39: 5). ${ }^{6}$ In fact, not only was Hölderlin not supposed to offer us a philosophy in waiting, but he was to be the source of the measure for this epoch: "We do not want to measure Hölderlin according to our time, but the opposite: we want to bring ourselves and those to come under the measure of the poet" (GA 39: 4). Not direction then, but a measure, a $M a \beta$; this is what the poets offer Heidegger; this is what they are for at the end of metaphysics. But in what sense and for whom? What is the nature of this poetic $M a \beta$ ? How does such a thing come to pass, even work? What kind of measuring is under discussion here? And why is it poetic? Why are poets the grounders of being? Finally, who shall be its standard bearers, and what future shall receive the Heimat, the "homeland," it demarcates? In other words, whom are these poets, or this poet, for?"

Where should we begin? Perhaps with Heidegger's ear. How does Martin Heidegger read? In what way are his stirrup, anvil, and hammer aligned such that textual vibrations strike him quite differently than they do the ears of other readers? As many know, Heidegger refuses to employ traditional poetic theory. 
In fact, Heidegger eschews poetics altogether, preferring to allow the poems he reads to determine for themselves the being of poetry. Why? Because traditional interpretation begins with an assumed understanding of the being of the poem. For example, psychoanalytic readings assume that the production of poetic discourse proceeds by way of unconscious forces saturated with subjective history. Likewise, Marxists employ a rhetoric of infrastructure and superstructure in accounting for the passage of social forces into poetry. Heidegger, on the other hand, wishes to allow the language of the poem to articulate its own being, and thus his interpretations refuse to assume a poetics, hoping to dissolve into the poems they would read. But how?

In answering this question, one must take note of the various studies which have appeared over the last fifteen years or so, notably Gerald Bruns' Heidegger's Estrangements and Véronique Fóti's Heidegger and the Poets. Also, one should note that in 1989, an entire issue of Research in Phenomenology was devoted to Heidegger's work on Hölderlin. And yet, among these studies, few have interrogated Heidegger's reading qua reading, and none with systematic intent. ${ }^{8}$ Indulge me, then, as I sketch such an account, engaging the distinction that anchors Heidegger's 1954 reading of Trakl, the distinction between Erörterung, "exposition," and Erläuterung, "clarification." Regarding the Erörterung, the "exposition," Heidegger informs us that, at least in its preliminary stages, it seeks to "locate" or "point out" (weisen) as well as "heed" (beachten) the Ort, the "site" of something. Heidegger calls the Ort the:

Spitze des Speers. In ihr läuft alles zusammen. Der Ort versammelt zu sich ins Höchste und Äußerste . . . [adding that] der Ort, das Versammelnde, holt zu sich ein, verwahrt das Eingeholte, aber nicht wie eine abschließende Kapsel, sondern so, daß er das Versammelte durchscheint und durchleuchtet und dadurch erst in sein Wesen entläßt. (UzS, 37; OWL, 159-60)

[tip of the spear. In it, everything runs together. The Ort gathers to itself from what is loftiest and most extreme ... [adding that] the Ort, the gathering, collects and preserves what has been gathered, although not as an encapsulating shell, but by shining through and illuminating that which has been gathered, thus releasing it, for the first time, to its Wesen.]

According to the passage, the Ort is a gathering force. Beginning from extremes, an Ort collects something within its reach and releases it to its Wesen. Given that the issue here is poetry, the Wesen in question lies in poetizing, in how a poem comes to poetize some matter or other. To remark upon the Ort of a poem is to consider the way in which the poem is "collected" and "released" into poetizing.

Let us consider the Ort at work. Poems say things in many ways. For example, a poem might recount a poet's aesthetic development, as does Wordsworth's Prelude, or develop aesthetic commitments, as does Stevens' Notes Towards a Supreme Fiction. A poem might also portray an event in the manner of Tennyson's The Charge of the Light Brigade, or, yet again, express intense feelings 
of alienation as does Sylvia Plath's Firesong. If we raise the question of the Ort in these cases, the issue concerns the gathering of such poems into their poetizing, into their disclosure of aesthetic development, a philosophy of art, a battle, or an author's sense of the corruption of life. This is not an issue of poetic content, however, but an issue of a poem's focus, qua poem, upon what it would say. Wordsworth's Prelude is about aesthetic development, but the question of its Ort is concerned with the poem's ability to articulate aesthetic development. Second, this is not an issue of what the poem expresses, as if the poem were a mere symptom of some deeper, infrastructural force. An Ort can never be expressed by any poem, for a poem must already be poetizing in order to express anything. And as the Ort is precisely the site of that gathering that allows expression, it must necessarily lie before every case of expression.

If an Ort is not expressed by a poem, where does one find it? On my reading, Heidegger opts to take the poem at its word, which is to say, he expects the language of the poem to articulate its own Ort. ${ }^{10}$ In seeking the Ort of the poetic, he seeks what we could call an Ur-poem, a poem of poetry that marks the rim of the Ort in which the language of the poem is gathered. Of course, Heidegger does not employ the figure of the Ur-poem, but he does write of a Grundstimmung (1934), a dichtende Wort (1942), a Gedichtete (1943), Grundworte (1946), and a Gedicht (1954), all of which supposedly articulate the essential site of whatever poetry is in question (respectively, Hölderlin's Germanien, Andenken, Der Ister, and the corpuses of Rilke and Trakl). Described generically, the play of an author's principal figures characterizes the being, or rather, the coming to be of the poem, i.e., its Wesen ${ }^{11}{ }^{1}$ For example, the interplay of Rilke's rhetoric of the heart, the open, nature, angels, lovers, and Orpheus stage the coming to pass of the being of the poem. Or, to invoke Hölderlin, figures like the river, the demigod, nature, divinities, and the flowers of the mouth should be taken, when read as a constellation, as contributions to a figurative dance enacting the being of the poem. ${ }^{12}$

What does it mean to take the poem at its word, however, particularly since Heidegger is so fond of claiming that the Ur-poem lies unspoken within an author's work?"13 According to "Sprache im Gedicht," one's reading must involve an Erläuterung, a "clarification." "Because the poet's singular Ur-poem always remains within the unspoken, we can situate its site only in trying to point to it by means of what the individual poems speak. And for that reason each poem will be in need of clarification" $(U z S, 38)$. Uncovering an author's Ur-poem thus involves a reciprocal strategy wherein one construes an Ur-poem out of select poems and then returns what has been construed to other poems in order to test the fidelity of one's "exposition."

In his 1943 reading of Hölderlin's Der Ister, Heidegger terms the stuff of these construals "annotations," Anmerkungen. According to Heiddeger, these annotations are markers (Merkmale), signs set along textual paths that direct one 
towards an Ur-poem. Through annotations, Heidegger thus reads until his feel for an Ur-poem and each particular poem coincides. As he writes in June of 1943:

Was immer auch eine Erläuterung vermag und was sie nicht vermag, von ihr gilt stets dieses: damit das im Gedicht rein Gedichtes um einiges klarer dastehe, muß die erläuternde Rede sich und ihr Versuchtes jedesmal zerbrechen. Um des Gedichteten will muß die Erläuterung des Gedichtes danach trachten, sich selbst überflüssig zu machen. Der letzte, aber auch der schwerste Schritt jeder Auslegung besteht darin, mit ihren Erläuterungen vor dem reinen Dastehen des Gedichtes zu verschwinden.... [If so] meinen wir beim wiederholenden Lesen, wir hatten die Gedichte schon immer so verstanden.

[Whatever else a clarification can or cannot do, this always applies: in order that what is purely poetized [our Ur-poem] may stand within the poem a little more clearly, the clarifying speech, at each turn, must break itself and what it has attempted. For the sake of what is poetized [the Ur-poem] the clarification of the poem must proceed in such a way that it makes itself superfluous. The final yet most difficult step of every interpretation consists in this, to disappear with its clarifications before the pure standing of what is poetized [the Ur-poem].... [If so] with repeated reading we'll suppose that we had always understood the poems in this way.] $(E H D, 9)^{15}$

The clarification of the Erläuterung therefore should dissolve into the exposition of the Erörterung, exposing an Ur-poem which marks and figures the Ort of poetizing itself.

Heidegger's readings are not intended to revolutionize literary history or criticism, however. Instead, they aim at revolutionizing our dasein. Let us turn, then, to the question of poetic founding, keeping in view the ground we have covered, for it will turn out that this Ur-poem holds a measure for those who have come to the end of metaphysics.

\section{An Added Dimension}

The poets, so we believe, remind the philosophers, again and again, of the world's baffling presence.

—Charles Simic

The key to poetic measure lies, I believe, in Heidegger's later discussions of "dwelling." In "Bauen, Wohnen, Denken," Heidegger claims that Wohnen involves the fundamental character (Grundzug) of human beings, it is "the way in which mortals are upon the earth" (VA, 142; BW2, 350). Or: "Dwelling . . is the fundamental relation of being according to which (demgemä $\beta)$ mortals are" (VA, 155; $B W 2$, 362). More specifically, "dwelling" names the way in which human 
beings undergo relations with themselves, the world, as well as Sein itself. In short, "dwelling" names our fundamental relation to the horizon of disclosure wherein beings appear, receive determinations, correspond to or elude determinations, etc. Dwelling is thus a matter of our Wesen, of how we come to be the beings we are.

What, though, is the relation of "dwelling" to poetry? In ". . dichterisch wohnet der Mensch..." Heidegger claims: "Poetizing [Dichten] is the originary allowance-of-dwelling [Wohnenlassen]" (VA, 196; PLT, 227). At the heart of Wohnen, therefore, Heidegger finds poetizing. Or, to be more precise, that which brings us into relation with the horizon of disclosure wherein we dwell itself occurs or comes to pass as the lassen of a Dichten. Or, in yet other words, poetizing holds the measure for human dwelling. But what could this mean?

According to Heidegger, dwelling is intimately bound to "building," Bauen, and vise versa. Dwelling involves our standing within a horizon of disclosure, what Heidegger at one point terms the Dimension (VA, 189; PLT, 220). And yet, we are able to undergo disclosures if and only if the Dimension has been "measured" or "surveyed" - vermessen (VA, 189; PLT, 221). In other words, the Dimension unfolds only in virtue of its being measured; that is, we dwell only in relation to some measure. But then, there can be no measuring-building unless we are already dwelling, unless we are already arising within a horizon of disclosure. As Heidegger writes in Bauen, Wohnen, Denken: "Only when we are able to dwell can we build" (VA, 155; $B W 2,362)$. The two are equiprimordial. Why? Consider the reverse. How could pure Dimension be disclosed? What would a dwelling-place be without a here or there? Put simply, there is no Dimension per se, only a given Dimension, one already measured. But then, neither is there building apart from some Dimension, apart from some horizonsuch a building would have no dimensions. ${ }^{16}$

This interdependence between building and dwelling is crucial for an understanding of poetry's role in our dwelling, for poetizing is, according to Heidegger, building par excellence.

Das wohnen aber geschieht nur, wenn das Dichten sich ereignet und west und zwar in der Weise, deren Wesen wir jetzt ahnen, nämlich als die MaßNahme für alles Messen. Sie ist selber das eigentliche Vermessen, kein bloßes Abmessen mit fertigen Maßstäben zur Verfertigung von Plänen. Das Dichten ist darum auch kein Bauen im Sinne des Errichtens und Einrichtens von Bauten. Aber das Dichten ist das eigentliche Ermessen, der Dimension des Wohnens das anfängliche Bauen. Das Dichten läßt das Wohnen des Men-schen allererst in sein Wesen ein. Das Dichten ist das ursprüngliche Wohnenlassen.

[But dwelling happens only if poetizing takes place and comes to pass (sich ereignet und west), and indeed in the way of . . . the measure-taking (Maß-Nahme) for all measuring (messen). This measure-taking is itself the most proper, not 
a bare gauging (Abmessen) with ready-made yardsticks (Maßstäben) for the preparation of maps. Likewise, poetizing is not building in the sense of raising and fitting buildings. Rather, poetizing, as the most proper appraisal (Ermessen) of the dimension of dwelling, is inceptual building. Before anything else, poetizing admits the dwelling of human beings into its Wesen [the manner of its coming to pass, or its essence]. Poetizing is the originary allowanceof-dwelling (Wohnenlassen).] (VA, 196)

Poetizing is an arranging of the Dimension at its "inception," its Anfang, an event of originary figuration. Dichten is thus originary "measure-taking." It does not simply measure a given dimension or area, but poetizes the measure of a horizon of disclosure itself. Now it is through this "most proper appraisal," this Ermessen, that poetizing builds a site for human dwelling. In arranging a Dimension, in providing a Maß, Dichten outfits a dwelling-place, as it were, such that we might dwell there.

At this point, at least two questions press themselves upon us. First, what is involved in "appraising" a dimension, or "surveying" it? Second, how does this activity enable dwelling? Let us begin with the former.

As noted earlier, one cannot apprehend the Dimension as if it were something present. Appraisal is thus not a rarefied form of poetic intuition. Instead, it must take place along side building, which in this case involves the production of poetic determinations. Let us consider an example, but one closer to our own period than the mytho-poetic musings of Hölderlin. A few years ago, after an already distinguished career, A. R. Ammons published Garbage, a poem ironically described at its outset as "that great poem the world is waiting for" and as one of "those celestial guidance systems." 17 The poem, dense and rich beyond what I shall say, presents us with a figure, a garbage mound, "which is about the pre-socratic idea of the / dispositional axis from stone to, wind / to stone," which is to say, it is about the generation of form, matter, and sense, of persons, twigs, and waste, of thumb nails, paper plates, and uranium deposits; all to say, it is about what is $(G, 20)$. The conceit works by taking the transmutations that govern the 'life' of the mound as the play of a necessity that moves through and animates all things as "eternity's glint: it all wraps back round, / into and out of form, palpable and impalpable" $(G, 22)$. And Ammons is rigorous in his deployment of this conceit, refusing to reduce it to the material or the spiritual, insisting instead that it includes both. ${ }^{18}$ Moreover, the work of transmutation along the "dispositional axis" that he terms a "spindle of energy" never becomes a thing among the things produced. Rather, the poem announces: "only born die, and if something is / born or new, then that is not it, that is not / the it: the it is the indifference of all the / differences, the nothingness of all the poised / somethings, the finest issues of energy in which boulders and dead stars float" $(G, 27)$. And finally, Ammons brilliantly figures his conceit by refusing to employ periods, opting instead for the colon (:) - 
a graphic instance of the "dispositional axis," the hinge upon which the poem's own sentences swing, the shoot through which all waste must travel. ${ }^{19}$

Back to our question as to the nature of poetic appraisal. Using Ammons as an example, we should begin by claiming that "appraisal," Ermessen, occurs within the production of lyrical determinations, taking "lyric" in its most extravagant sense: poetry, neither narratively based nor dramatic in form, which grapples with concerns and questions considered essential to human existence. ${ }^{20}$ And yet, the production of names does not in itself constitute poetic appraisal. If it did, Dichten would in fact be analogous to the "raising and fit-ting of buildings," something Heidegger denies, claiming instead that Ermessen involves anfägliche Bauen, "inceptual building." But then, what does it involve?

Let us consider this appeal to the Anfang. In his reading of Hölderlin's Germanien, Heidegger distinguishes between the Beginn and an Anfang, tethering the latter to the Ursprung, the origin. A Beginn marks the actual onset of something, for example (and it is Heidegger's), a change in the weather "begins" with an event, say a storm. The Anfang, however, lies in the atmospheric changes that lead to the storm. Thus a "Beginn ist jenes, womit etwas anhebt, Anfang das, woraus etwas entspringt," that is, a "Beginn is that with which something commences, an Anfang that from which something originates, leaps forth" (GA 39: 3). The Anfang thus marks a gathering of elements that results in a certain event; it is the Ur-sprung, the source from which some event leaps forth, "ent-springt." 21 If Dichten is anfängliche Bauen, then it must "appraise" the Dimension at the scene of its emergence, in its leaping forth. But if the Dimension only comes to be alongside of a "surveying," a Vermessen, in order to catch the Dimension at the scene of its emergence one must catch it as it opens in and alongside its surveyance. Or to use the language of the Kunstwerkes piece, the task involves "appraising" the "clearing of openness" (the Lichtung) within the "arranging" (the Einrichtung) of "sites filled by present beings [einer von Anwesenedem erfullten Stätte]" $(H, 48 ; B W 2,186)$. But is not poetry responsible for the surveyance? Indeed. Thus appraising involves tracking the gathering of the Dimension within the poem's own language. In the Ammons poem, this would involve tracking the gathering of those fundamental, poetic names, names like "garbage," "dispositional axis," "spindle of energy," etc., which purportedly "survey" the Dimension of human dwelling.

On the reading being developed here, the claim is that poetic appraisal, Ermessen, takes place when the names that arrange and establish the Dimension or an Open-region are tracked with regards to their own emergence. But how is a poem to do this? Said briskly, by poetizing naming itself, or rather, by poetizing poetizing. In the Ammons poem, this occurs when the figure of the garbage mound, with its endless transmutations, turns back upon the poem itself, as in the following passages: "there is a mound, / too, in the poet's mind 
dead language is hauled / off to and burned down on, the energy held and / haped into new turns and clusters, the mind / strengthened by what it strengthens" $(G, 20)$. And less directly: "but we are natural: nature, not / we, gave rise to us: we are not, though, though / natural, divorced from higher, finer configurations: / tissues and holograms of energy circulate in / us and seek and find representations of themselves / outside us, so that we can participate in / celebrations high and know reaches of feeling / and sight and thought that penetrate (really / penetrate) far, far beyond these our wet cells, / right on up past our stories, the planets, moons / and other bodies... oh yes, in the abiding where / mind but nothing else abides, the eternal, / until it turns into another pear or sunfish" $(G, 21-22)$. And finally, as we've already noted, this poem too is garbage, punctuation and all, a Schwingungsraum of cesspool choirs.

But where is the clearing of openness in all this? How does this recoil of the garbage figure finger the rim of an openness whose clearance enables its own figuration? A difficult question, for here assertions fail, begging the question, overlooking their own Anfang, forgetting their own reliance upon names, upon an open already cleared. The mute limits of assertion recall the fate of the Urpoem's articulation of the Ort of poetizing. In its reflexivity, the Ur-poem neither expresses nor represents, at the level of content, its own gathering, for such forms presuppose what they would provide. Should one conclude, therefore, that "appraisal" is not itself a naming? This seems too hasty. ${ }^{22}$ Does not the Ammons poem direct us towards its source, and with names: "a spindle of energy," a "dispositional axis," the movement of matter into spirit into matter, ellipses dotting the dance? And does not it also push past these names to "eternity's glint," even drawing when speaking fails, i.e., ":"? Most certainly, but we must not be misled, for no one figure, line, phrase, or name (or sum of them all) traces the way in which the open is cleared. Instead, the intersection of all these forces directs us towards their scene of emergence, their Ort, that is, dances of figures push past themselves to their horizonal rim, where they fall off, taking us with them: "dance / peopling the centers and distances, the faraway / galactic slurs even, luminescences, plasmas, / those burns, the same principle: but here on / those heights, terns and flies avoid the closest / precincts of the flame, the terrifying transformations, / the disappearances of anything of interest, / morsel, gobbet, trace of maple syrop, fat worm" $(G, 31) .{ }^{23}$ To dwell, however, there is no avoiding the "closest precincts of the flame."

Poetizing, as measure-taking, appraises the Dimension in poetizing its own emergence by waxing lyrical and reaching past these flourishes. Articulating the clearing of the Dimension, poetizing tracks the emergence of its own figuration. But note: this is precisely what takes place in the Ur-poem - a poetizing of poetry, a poetizing of the Anfang, of language's leap into poetry. Can we claim, therefore, that the poetic "appraisal" of the Dimension takes place in the language of the Ur-poem, in that language's turn towards an appraising figuration 
of its own Ort? But this rings absurd, for it seems to bind humans to the being of poetry. And yet, Heidegger has claimed that human beings dwell poetically. Where is the sense in this? I think it hinges on Heidegger's claim that one cannot think the Wesen of any being except through a language of Wesen, and thus necessarily upon some account of the Wesen of language. In "... dichterisch wohnet der Mensch ...," he writes:

Woher nimmt der Mensch überhaupt den Anspruch, in das Wesen einer Sache zu gelangen? Der Mensch kann diesen Anspruch nur dorther nehmen, von woher er ihn empfängt. Er empfängt ihn aus dem Zuspruch der Sprache. Freilich nur dann, wenn er und solange er das eigene Wesen der Sprache schon achtet... . Denn eigentlich spricht die Sprache. Der Mensch spricht erst und nur, insofern er der Sprache entspricht, indem er auf ihren Zuspruch hört. (VA, 183-84; PLT, 215-16)

[From where do humans, as a whole, make the claim (Anspruch) of having arrived at the Wesen of something? Humans can make such a claim only from where they have received it. Humans receive such a claim from the exhortation (Zuspruch) of language. But of course, only when and so long as they abide by the most proper Wesen of language. . . Because, properly speaking, language speaks. Humans speak first and only insofar as they co-respond (entsprechen) to language, listening to its exhortation.]

Generically, we could say that humans dwell by co-responding to a horizon of disclosure, by being always already amid disclosure. But our entry into this "midst" only comes to pass when we co-respond to the "exhortation" of language, that is, we come to be among disclosures in a co-responding to the address of language. And thus it is alongside of a response to the exhortation of language that we arrive at the Wesen of something, including ourselves. ${ }^{24}$ Concerning the Ur-poem, then, my claim is that by "appraising" its own emergence into language, the Ur-poem engages and figures a relation between its own determinations and their emergence into language that unveils or "surveys" the Wesen of language. In so engaging the Wesen of language, the Urpoem thus provides an encounter with language, one through which all wesentlich inquiries might travel, including the pursuit of the originary scene of human dwelling. In other words, the Ur-poem produces an Ursprache, a language which "appraises" the Dimension wherein all other disclosures come to pass. ${ }^{25}$ When Heidegger claims, therefore, that the "co-responding through which humans properly listen to the exhortation of language is that saying that speaks in the element of poetizing," we can regard poetizing here as the doubling turn of a language tracking its own originary emergence. We might even say that a "proper listening" to the exhortation of language involves a figurative "appraisal," and that this is precisely what the poetizing of the Ur-poem accomplishes. ${ }^{26}$

It seems that the self-figuring play of the Ur-poem might in fact be bound to the question of human dwelling. And yet, what does Heidegger mean when 
he claims that this form of poetizing "allows" human dwelling, that Ur-poetry involves a Wohnenlassen? This emphasis on lassen rings in obvious contrast to a rhetoric of causality. If we are to understand how an Ur-poem allows us to dwell, we will have to work our way out of some common intuitions concerning the nature of production. One can see why Heidegger would not want to speak of poetry as the causal force behind human dwelling. Such a notion is wedded to the notion of efficient causality, a concept Heidegger considers a perversion. ${ }^{27}$ More importantly, efficient causality involves two present forces meeting one another, resulting in some effect. Where in such a schema can one find, however, the subtle play of Lichtung and Einrichtung? For all intents and purposes, the event wherein the open is cleared, an event assumed in all relations, causal or otherwise, is overlooked when the rhetoric of efficient causality is employed. But revealing the clearing of the open is the key to poetic building. In fact, the Ur-poem only finds its way to its own Ort by attending to the clearing of the open that underwrites its own emergence into language. It seems clear, then, that poetic building does not cause some Dimension to unfold as Hume's billiard balls cause, or seem to cause, one another to bound along the rails. But how are we to understand this?

Let us work more carefully with "Die Frage nach Der Technik." After refusing to consider the concept of the cause within the framework of efficient causality, Heidegger writes:

Causa, casus, gehört zum Zeitwort cadere, fallen, und bedeutet dasjenige, was bewirkt, daß etwas im Erfolg so oder so ausfällt. Die Lehre von den vier Ursachen geht auf Aristoltes zurück. Im Bereich des griechischen Denkens und für dieses hat jedoch alles, was die nachkommenden Zeitalter bei den Griechen unter der Vorstellung und dem Titel "Kausalität" suchen, schlechtin nichts mit dem Wirken und Bewirken zu tun. Was wir Ursache, die Römer causa nennen, heißt bei den Griechen aĩ ov, das, was ein anderes verschuldet. Die vier Ursachen sind die unter sich zusammengehörigen Wesien des Verschuldens. (VA, 16; BW2, 314)

[Causa, casus, belongs to the verb cadere, to fall, and means that which effects [things] such that, as a result, such and such comes about. The doctrine of the four causes comes from Aristotle. Within and for the realm of Greek thought, however, everything for which later ages search among the Greeks with the conception and term "causality" has simply nothing to do with working-upon and effecting. What we name "cause," what the Romans name causa, is called by the Greeks aition, that to which something else is indebted. The four causes, all belonging to one another, are ways of being-responsiblefor-something. $]^{28}$

First, note that the issue is the Ursache, the first thing, the originary matter. What is at issue then is the origin, the Ursprung. One should expect to confront, therefore, matters concerning what must have occurred in the first place given 
that things are the way they are. ${ }^{29}$ Second, Heidegger, with characteristic and exaggerated severity, is attempting to wrest the notion of causality away from the Latin world in order to give it a Greek spin. ${ }^{30}$ Third, he translates the thought of the Ursache within terms of indebtedness, even guilt-Verschulden, which Lovitt has rendered as "being-responsible-for-something." "31 Now in its most general sense, Heidegger understands Verschulden to involve "bringing something to presence." More precisely, the four ways of being-responsible-forsomething have "den Grundzug dieses Anlassens in die Ankunft," that is "the fundamental characteristic of releasing something into its arrival" (VA, 14; $B W 2,316)$. Why the emphasis on lassen? As I noted earlier, I think it has to do with Heidegger's attempt to recover a sense of the clearing of openness within the event of presencing. If we set at the heart of causality this notion of "releasing something into its arrival," we engage several questions. First, we render presencing an event, thus provoking us to seek the origin of what has come to pass. Second, we are made aware of the temporality of presencing in the fact that presencing happens. Third, the moment of release adds a dimension to the interaction of those forces or beings that in fact emerge into presence. And it is this added dimension that concerns us here, for it marks both (a) the dimension of the Ort as a gathering force at work in the language of the poem and (b) the dimension of the Dimension from which poetic building takes its leave and to which it returns human dwelling.

We might deepen this discussion by noting that Heidegger eventually claims that the essence of Kausalität is Veranlassung, meaning "to occasion" but also to "call forth" (VA, 14;BW2, 316). This means, I take it, that Heidegger would have us regard the inception or origin of something as a "calling-forth" of something into its arrival, into presence, an arrival we earlier described in our discussion of the Anfang as an entspringen, a "leaping-forth." According to Heidegger, then, "to occasion" something is not to produce it ex nihilo, or to run into it thus redirecting its passage through space, but to gather and start it down some path, to direct its arrival in a certain way, to call it forth to a certain way of being. ${ }^{32}$ Now this should recall our earlier discussion of the Anfang and the storm. The Anfang is not the Ur-production and ignition of the storm's form, matter, and end, but a gathering of those moments, a gathering that allows them to arrive into presence. Why "allow"? Because the gathering is not itself a present force among those gathered, but the scene of their convergence, or even what calls them to convene. ${ }^{33}$

Perhaps we are in a better position now to make sense of the claim: "Poetizing is the originary allowance-of-dwelling (Wohnenlassen)." In allowing us to dwell, poetizing does not simply erect a dwelling, leaving us to worry about the perspicuity of our view. Instead, it calls us forth to a site wherein we might dwell. Now recall that dwelling, wohnen, names the way in which humans undergo relations with things themselves, even the event of presencing itself. As 
Heidegger says, it is our way or manner of being upon the earth. To say then that poetizing allows us to dwell is to say that poetizing calls us forth into this way of being upon the earth; that is, it enables us to arrive into presence in a certain way. More specifically, it allows us to arrive into presence within the appraising-figuration of the Ur-poem. On the one hand, the Ur-poem arranges a Dimension through the interplay of its lyrical determinations: river, demigod, divinities, flowers (Hölderlin); angel, heart, Orpheus, rose (Rilke); twilight, silence, madness, wall (Trakl); spindle, colon, trash, and more trash (Ammons). This is the moment of Einrichtung, of building and arranging across an open region. On the other hand, the Ur-poem reaches past these determinations to the point of their and its emergence, to the Ort, the "tip of the spear" around which "everything runs together." And in so reaching, it unveils the clearing of openness, the Lichtung, which opens the Dimension within which (a) the language of the poem unfolds and (b) an open region is arranged. And it is this exposure of the opening open, through and beyond the Ur-poem's own lyrical determinations, which calls us forth to a certain kind of presencing. More specifically, the Ur-poem's exposure of the Lichtung tags us with a language attuned to the clearing of the open that foregrounds, even underwrites, the very emergence of things.

An example. In Garbage we hear: "holy, holy, / holy, the driver [of a garbage truck] cries and flicks his cigarette / in a spiritual swoop that floats and floats before / it touches ground: here, driver knows, / where the consummations gather, where the disposal / flows out of form, where the last translations / cast away their immutable bits and scraps; / flits of steel, shivers of bottle and tumbler, / here is the gateway to beginning, here the portal / of renewing change, the birdshit, even, melding / enrichingly in with debris, a loam for the roots / of placenta: oh nature, the man on the edge of the cardboard-laced cliffs exclaims, that there could be a straightaway from the toxic past into / the fusion-lit reaches of a coming time!" $(G, 28-29)$. It is this "gateway to the beginning," or rather Ursprung, which concerns us, this "portal." The Ur-poem calls us forth into this portal, sets us there - allows us to undergo disclosure under its canopy. But the issue is not simply the open region of disclosure, as if that were the scene of human dwelling. As we have noted repeatedly, there is no such thing - we are never simply there, in the open. The double saying of the Ur-poem is thus the key, for human dwelling is precisely doubled in this way: present, alongside others and things, but also among them, among "this" and "that," which is to say, just past them (and ourselves) as well, both "mist" and "matter." 


\section{Exploring the Open Ranges}

The skreak and skritter of evening gone

And grackles gone and sorrows of the sun,

The sorrows of the sun, too gone ... the moon and moon,

The yellow moon of words about the nightingale

In measureless measures, not a bird for me

But the name of a bird and the name of a nameless air

I have never - shall never hear. And yet beneath

The stillness that comes to me out of this, beneath

The stillness of everything gone, and being still,

Being and sitting still, something resides,

Some skreaking and skittering residuum,

And grates these evasions of the nightingale

Though I have never - shall never hear that bird.

And the stillness is in the key, all of it is,

The stillness is all in the key of that desolate sound.

—Wallace Stevens, "Autumn Refrain"34

If the Ur-poem in fact calls us to a scene of dwelling through its figurative appraisals, one must ask: How should this figuration be regarded once it has been built? What does it mean to dwell through an Ur-poem? What is a Wohnung? Or, how does an Ursprache engage and inform a Dimension of disclosure?

Let us begin with some preliminary observations. If our Wohnung is founded in the language of an Ur-poem, then the figures of that poetry mark the limits of the horizon of disclosure even as they gesture past those limits. In this regard, then, an Ursprache is akin to Kant's notion in the Critique of Pure Reason of Sinnlichkeit, "sensibility," the a priori arena wherein objects of intuition are given to us (A19/B33). And yet, the productive and responsive play of the language of the poem is not the work of a transcendental subject. Instead of delimiting the horizon of disclosure within the intuitional folds of space and time, the Ur-poem itself figures the Dimension of human existence. For example, if we follow Hölderlin as read by Heidegger in the 1950s, we will find ourselves in a dwelling built around the play of the Geviert, the fourfold, a constellation of earth and sky, divinities and mortals. Or, to invoke Rilke, our Wohnung might be figured in the spherical play of erotic life turning into death, turning into life.

While the analogy with Kant has obvious limits, it does underscore one central fact: Ur-poetry does not create a world thing by thing, but determines or occasions (recalling our discussion of Veranlassung) how a "world worlds," how the play of its presences and absences swirl about us. In other words, in allowing us to encounter the Wesen of language at the point of its inception, neither the Ur-poem nor the poet name discrete things. As Heidegger writes, the fact 
that poetic language figures our horizons of disclosure "never means that language, in any old meaning picked up at will, immediately and definitively supplies us with the transparent Wesen of the matter like some object ready to be used" (VA, 184; PLT, 216). Why? As we've seen, the poetry unfolding here neither expresses nor represents the Ort of its and our gathering. In other words, it is nonpropositional; no predicates are ascribed to individuals (e.g., this rock is garbage) or classes (all / some rocks are garbage). Heidegger is not proposing that poetic names somehow magically summon or control the "essence" of things. Or to put the emphasis elsewhere, this is not a referential poetry, not a poetry that aspires to name anything at all, but one that figuratively traces the rim of its and our being.

But how? How does the language of Ur-poetry stand in relation to the Dimension of human dwelling? One might think, following Schürmann, who also begins with Kantian intuitions about the nature of human dwelling, that Ur-poetry supplies "inceptual categories of presencing" according to which disclosures take place. Schürmann believes that properly understood, the language of "category" captures the way in which building and dwelling intertwine. He writes: "If it is understood that the traditional term 'category' is here shorn not only of all ousiological and subjectivist connotations, but also of all references to phenomenal regions .... if it is understood, in other words, that categorein, 'to accuse,' no longer means 'to address oneself to entities as such,' but to address presencing and its manifold ways of differing from the economies of presence, then nothing prohibits rehabilitating this venerable word." ${ }^{35}$ While there is a certain attractiveness to Schürmann's tack, its emphasis on the structural is troubling, for it leaves the event of figuration no longer poetic. In a way, Heidegger anticipates this trouble when he claims in the Beiträge that the language of categories remains inextricably tied to the language of Urteil, judgment (GA 65: 135-36). This marks a problem because within what claims to be originary, it re-inscribes a more original governing agency. In terms of the language of the Ur-poem, this would mean that poetic building is actually the product of a deeper, extra-poetic agency, and Heidegger is quite clear that with regards to the language of the poem, the origin lies within poetic language itself.

On first glance, Schürmann seems to elude our worry, for his central claim is that the $\dot{\alpha} \propto \chi \eta \dot{y}$ of these categories is in fact an-archic. But does not categorical language re-inscribe a judging agent into presencing? In a fascinating way, this re-inscription occurs in Schürmann's own discussion. In elaborating his anarchic categories of presencing, Schürmann is compelled to chastise Heidegger for what he terms a "category mistake" (HBA, 176-77). On the one hand,

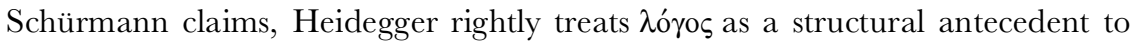
the event of presencing. On the other hand, however, Heidegger also proceeds as if $\lambda$ ó $\gamma$ os marked an actual, historical antecedent to the event of presencing. 
And this, Schürmann continues, confuses a category with its application. And yet, how could such be avoided when the issue is presencing? If categories are to figure disclosure, one cannot keep them "categorically" distinct from what

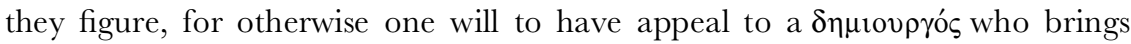
together the categories with the stuff to be fashioned according to their lights. And this is precisely, I take it, the heart of Heidegger's worry in the Beiträgecategories remain parasitic upon some agent who applies them. We need to reach past a rhetoric of categorein, therefore, in order fathom the work of Urpoetic figurations.

I am inclined to find in Schürmann the limits of our Kantian intuitions regarding the way in which Ur-poetry comes to arrange an open Dimension of disclosure. Perhaps we might draw a more productive lead from a source less ensnared in the traditions of German Idealism. In order to de-subjectivize and de-transcendentalize poetic building altogether, Andrzej Warminski has suggested that we understand the figurative power of the poetic word in terms of catachresis, that is, in terms of a certain class of names that are thoroughly metaphorical, e.g., mountain face. He opts for this term because "it is the figure of all figuration; but in being such, it is a monstrous figure in so far as it un-says its referential pretensions, that is, undoes them." ${ }^{36}$ Monstrosity arises because within the very idea of catachresis a naming lurks that occurs in deferral; that is, built into the name "mountain face" is the thought that this part of the mountain bears its name only through the intercession of a third, and this third defers inquiry into the origin of poetic building; i.e., such inquiry only encounters a clearing of the openness that enables, but is not present in, the language of the poem, except perhaps as a "stillness keyed in a desolate sound," to recall Stevens' "Autumn Refrain." Following Warminski, therefore, we could regard poetic building as the work of catachresis, the presentation of infinitely deferring metaphors.

Warminski's tack troubles me, however, for it draws the language of Wesen outside of the work of poetizing and into the history of poetics. Moreover, it leaves us asking about the Wesen of this term "catachresis" that proposes to name the figuring work of language. Now Warminski is shrewd enough to anticipate this concern, and thus refuses to regard catachresis as a name at all. Instead, it eludes the realm of semantics as a "syntactical marker," a "syntactical plug," a site in "language's material conditions of possibility" (RII, xxxxxxiii, liii, 70). This position is untenable, however, for two reasons. First, the very distinction between syntax and semantics is a semantic one, and thus the logic of Warminski's claim fails from the outset to escape the binds of semantics, even though he insists that this sense of "syntax" is a nondialectical other to semantics. Second, Warminski oddly refuses to interrogate the Wesen of his own language of "syntax" and "language's material conditions of possibility." Instead, he proceeds as if these were not names themselves. I think his attempt 
to account for the work of poetic figuration ultimately fails to engage the problem, therefore, or rather, it fails to accept that poetic names, semantically charged, are the only originary signs we have.

While Warminski's turn to the rhetoric of poetics does not, I believe, allow us to come to terms with the nature of poetic dwelling, his emphasis upon the "monstrosity" of poetic figuration merits our attention, for it captures a key element in the drama of poetic building and dwelling. In the Kunstwerkes piece, Heidegger writes:

Je einsamer das Werk, festgestellt in die Gestalt, in sich steht, je reiner es alle Bezüge zu den Menschen zu lösen scheint, um so einfacher tritt der Stoß, das solches Werk ist, ins Offene, um so wesentlicher ist das Ungeheure aufgestoßen und das bislang geheure Scheinende umgestoßen. Aber dieses vielfältige Stoßen hat nichts Gewaltsames; denn je reiner das Werk selbst in die durch es selbst eröffnete Offenheit des Seienden entrückt ist, um so einfacher rückt es uns in diese Offenheit ein und so zugleich aus dem Gewöhnlichen heraus. Dieser Verrückung folgen, heißt: die gewohnten Bezüge zur Welt und zur Erde verwandeln und fortan mit allem geläufigen Tun und Schätzen, Kennen und Blicken ansichhalten, um in der im Werk geschehenden Wahrheit zu verweilen. $(H, 52-53 ; B W 2,191)$

[The more solitarily the work stands on its own, established in a form, seeming to let go, cleanly, all ties to human being, the more simply does it strike into the open that such a work $i s$, the more essentially is the monstrous thrown open and what was long-familiar over thrown. But this manifold striking and throwing is nothing violent; for the more purely the work itself is carried off into the openness of beings, what it itself has opened, the more easily does it throw us into this openness and, simultaneously, out of the commonplace. To submit to this displacement, that means: to transform accustomed ties to world and earth and, henceforth, to keep oneself from all well-known ways of acting and assessing, knowing and viewing, in order to tarry with the truth occurring in the work. $]^{37}$

This is a remarkably rich passage. Let me note several things. First, if we accept that "truth" here refers to what is disclosed by the work, what comes to unconcealment in the work, then it would seem that the truth with which we are to tarry is that which the work reveals as "monstrous," the Ungeheure. But what is monstrous here? Truth, that is, unconcealment itself. Heidegger writes: "Die Offenheit dieses Offenen, d.h. die Wahrheit, kann nur sein, was sie ist, nämlich diese Offenheit, wenn sie sich und solange sie sich selbst in ihr Offenes einrichtet. Darum muß in diesem Offenen je ein Seiendes sein, worin die Offenheit ihren Stand und ihre Ständigkeit nimmt [The openness of this open region, that is, truth, only can be what it is, namely, this openness, if and so long as it arranges itself within its open region. In this open region there must be, therefore, a being in which openness takes its stand and attains constancy]" $(H, 47 ; B W 2,186) . .^{38}$ As I see it, the point is that the originary or inceptual site 
of disclosure, what we have regarded as an Ort of poetic figuration and the open dimensions of human dwelling, comes to presence in a being, in the presencing of a being. (In our context, this being would be a poetic determination.) And yet, this dependency on a presencing being (or a word) conceals the moment of Lichtung, of clearing; that is, a being or poetic determination cannot re-present the clearing of that openness that enables it. Thus: "Die Wahrheit west als solche im Gegeneinander von Lichtung und zweifacher Verbergung [Truth, as such, essentially comes to pass in the opposition of clearing and double concealing]" $(H, 47 ; B W 2,185) \cdot{ }^{39}$ But what is monstrous in this? Let us consider three things. ${ }^{40}$

First, a vast power is at play in the work of art insofar as it brings about unconcealment, truth, in an originary fashion. We are discussing here the gathering of a horizon of disclosure, a calling-forth of something to its essence, a gathering from the "extremes" to recall our earlier discussion of the Ort $(U z S$, 38; OWL, 159-60). At work in the work of art, therefore, in the Ur-poem, is a monstrous power of sorts, and Heidegger's appeal to the "monstrous" conveys this. ${ }^{41}$ Second, the sheer un-representability of the clearing of openness is tinged with the monstrous, but in the sense of the extraordinary. Concerning Hölderlin's use of "Ungeheure," Heidegger writes of the Außergewöhnliche, that which is not simply nonordinary, but ungraspable within the realm of the ordinary (GA 53: 77-78; DI, 63-64). In other words, the event of unconcealment cannot be accounted for as something either zuhanden, ready-to-hand, or vorhanden, present-at-hand. In fact, the event of unconcealment is never "at hand" at all, and thus not a matter for re-presentation. With regard to truth as $\dot{\alpha} \lambda \dot{\eta} \theta \varepsilon \iota \alpha$, John Sallis has written of a "divergence from nature in nature," of a force at work in nature that is not present in nature..$^{42}$ In this context, I think we could speak of "a divergence from the ordinary within the ordinary," and stress the within, for as we have noted, "in the open region there must be a being in which openness takes its stand and attains constancy."

A third moment concerns the most obvious sense of the monstrous: the frightful. Heidegger himself notes that the emergence of the monstrous subjects us to displacement. Note the strength in the word Verrückung: displace, shift, disarrange. And then, to be verrückt is to be mad, crazy, insane, cracked. As the monstrous is thrown open, we are jolted out of ourselves. More specifically, we are thrown out of accustomed ways of "acting and assessing, knowing and viewing." In other words, the emergence of the monstrous brings with it a kind of exile, a banishment from what, until then, had carried us along. And yet, Heidegger downplays this aspect of the monstrous, claiming that it is "nothing violent." On the one hand, I can appreciate his resistance. If the work of art were viewed as violent, if its transformative power were regarded as a cause, then we again would lose the moment of the clearing in the arrangement of an open region of disclosure. Also, I think Heidegger is at pains to free the power 
of the work of art (and unconcealment itself) from human subjectivity. As he notes, a work of art draws us towards truth the more cleanly it cuts "all ties to human being." But if we stress the violent nature of the work's impact, we draw the work back into a relation with us and run the risk of reducing its power to reader response, thus losing the originary altogether. ${ }^{43}$ And yet, one cannot deny the transformative power of exile. Why, even as it opens the openness of beings, the work itself is "carried off" into that openness, that is, it is entrückt. As with Verrückung, this is a powerful word. Not only does it suggest being carried off, but it also connotes ecstasy and rapture. It is as if the work, in being drawn towards its own Ort, drew us as well, called to us, thus carrying us off in the wake of a move towards its source. And from the perspective of the everyday, of accustomed, habitual comfort, this can be a moment of violence, of uprooting, Heidegger's disclaimer notwithstanding.

This language of the monstrous highlights, I think, an integral moment in poetic founding. Recall that the Ur-poem enables us to dwell because, in exposing its own Ort, it calls us to the originary site of disclosure by allowing us to attend to the essence of language. And in doing so, it provides an Ursprache that figures that site, that is, which brings or gathers all determinations to the scene of their emergence. Now, as we have just seen, something monstrous is at work, and both within the call to the originary site, and the site itself, for therein lurks: (1) a double-concealment amidst a powerful unconcealment, (2) an event not translatable into rhetorics of presence, re-presentation, or expression, (3) a moment of ecstatic exile from what had been ordinary, and (4) a no doubt frightful encounter with the uncanniness of disclosure per se. On the one hand, then, the Ur-poem calls us forth to a site of dwelling, allowing us to tarry there (verweilen). On the other hand, it also jolts us, yanks us away from the customary. Alongside poetic founding, we should expect, therefore, to encounter exile, and perhaps a certain kind of madness.

Given this emphasis upon monstrous excesses in the open region to which the Ur-poem calls us, one cannot help but wonder about the importance of any given determination in the work of poetic founding. After all, if the point is just to announce the abysmal grounding of beings, it is not clear that any founding poem need have more than one monstrous figure. This is a reasonable question, but it conceals an important misunderstanding as well as a profound limit to the language we have employed thus far. We tend to speak and write as if the open region of beings, the horizon of disclosure, were a place through which all beings traveled. If this were the case, then we could rest with a few names that locate it, point it out, if only under erasure. But such a picture is misleading, for the open region of beings is less a place than an event of clearing that accompanies all presencing. The clearing of openness is not some particular thing in need of a clever name, but an event that accompanies and haunts all names, all figures. An Ursprache is thus not a collection of names 
for some monstrous element of the world, but a play of figures that unveils the world in its monstrous worlding. Or, in less dramatic form, the Ur-poem provides us with a set of figures whose interaction and play enable us to engage beings in the event of their presencing and not just as present beings. The figures of the Ur-poem thus accompany particular disclosures like shrouds, drawing them back towards the originary site of disclosure. And this is the point - not simply to point out the differential nature of disclosure, but to provide a language that can bring an entire range of disclosures back into the folds of this differential site.

This section's initial question is still with us, however. How should we regard the figures that make up an Ursprache once they are set into a form and begin to gather disclosures within their monstrous reach? In other words, what does it mean to speak, or to speak within, such a language? Having rejected the paths offered by Schürmann and Warminski, what are we to say about Ur-poetry?

I think we might take our leave from a determination invoked in Heidegger's 1942 course on Hölderlin's Andenken. In that course, Heidegger regards what is poetized, the Gedichtete (our Ur-poem) as the product of a dichtende Wort, a "poetic word" that überdichtet, "over-poetizes" (as one might overrun) the language of the poem. More specifically, it "öffnet und verschließt einen Reichtum, der unerschöpflich ist, weil er der Art des Anfänglichen und d.h. des Einfachen hat [opens and secures an abundance that is inexhaustible because it has an inceptual, and that means simple, character]" (GA 52: 13). The dichtende Wort calls the language of the poem to an abundance, but in the sense of a "wealth of opportunity." And it is this wealth of opportunity that concerns us. If you recall, the site of human dwelling involves the ways in which human beings undergo disclosure, that is, it involves our relations or ties to the earth and world, our "ways of acting and assessing, knowing and viewing" $(H, 53$; $B W 2,191) .{ }^{44}$ The site of human dwelling is thus a site of opportunity, of possible ways of engaging beings as they come to presence, e.g., faces, stones, rivers, trash bins, dingoes, cottage cheese, even poems. Given this, I think the key to understanding the existential force of Ur-poetry lies in this abundance.

In explicating the nature of poetic abundance, Heidegger writes of Schwingungsräume, what I earlier translated as "ranges of vibration." 45 What is striking about this term is its musical connotations - chords and strings vibrating, producing ranges of sound. And these connotations are not limited to this word. Across Heidegger's texts, one finds musical figures. In Der Satz vom Grund, he refers to the Tonart, the "tonality" of the principle of sufficient reason, and views his accentuation of moments therein, e.g., the copula, as Betonungen, "intonations" (SVG, 91-92 and 86; $P R, 50$ and 46). ${ }^{46}$ Likewise, in a late reading of Hölderlin, he focuses upon the Grundton of a verse, though one can find this language as well in "Sprache im Gedicht" and "Der Satz der Identität" (VA, 185; 
$U z S, 78 ; I D, 12-13)$. And then, the notion of a Grundstimmung is rife with musical senses given the verb stimmen can mean "to tune an instrument." Finally, Heidegger regards the figure of the art work, within which truth comes to pass, as a kind of fugue. Of a work's Gestalt, he writes: "Sie ist das Gefüge, als welche der Riß sich fügt. Der gefügte Riß is die Fuge des Scheinens der Wahrheit [Figure is the fugal structure in which the rift composes itself. This composed rift is the fugue of truth's shining]" $(H, 50 ; B W 2,189) \cdot{ }^{47}$ Where is all of this heading? I want to claim that the Ur-poem animates human dwelling like a tonal scale animates a work written within its confines. In other words, the Urpoem institutes "ranges of vibration" that effectively tune disclosures such that they and we are brought back to the site of our mutual emergence as we leap or sound forth.

Consider the matter this way. A given poetic figure marks a Grundton, a "fundamental tone": for example, Rilke's "angel," Hölderlin's "river," Trakl's "leprosy." Now within a given corpus, several figures come together to produce a tonality, a tonal range, what I take to a Schwingungsraum. For example, we could speak of the tonality of Ammons's poem in terms of matter, spirit, the dispositional axis, garbage, ":," energy, etc. When we do, it is crucial to prioritize the interplay of the whole rather than assemble the figures in a cumulative fashion. In other words, no one word speaks on its own. ${ }^{48}$ With this play of figures in tow, I think we can understand the Ur-poem's monstrous force within human dwelling as we do the force of a tonal scale within a given piece of music. Just as every piece and every note within those pieces sounds out within a tonal scale, so each disclosure enters the scene of human dwelling having taken its leave from the tonal backdrop of an Ur-music. ${ }^{49}$ Thus every particular, say, my hand, or my toes moving in my shoes, or the view from my window, some voices down the hall, or the milk souring in my refrigerator while my nieces dance and sing in Indiana - each would have a place within the range of vibration that flows from a figurative tonality.

If we follow the view being sketched here, and regard poetic founding as the institution of figurative tonalities within the scene of human dwelling, we will have to regard these tonalities as nonreferential. That is, the Ur-music of the Ur-poem must be a matter of absolute music. The term "absolute music" has an interesting and rich history, one tied to a legitimation crisis concerning purely instrumental music. ${ }^{50}$ Most generally, the term reflects a commitment on the part of theorists like Eduard Hanslick to liberate instrumental music from the derivative status it held well into the eighteenth century. That such a liberation would be necessary may strike twentieth century listeners as strange, but even in the nineteenth century, people like Wagner argued that instrumental music remained incomplete without the presence of word-driven texts. At the heart of this notion of absolute music there lurks, therefore, the idea that instrumental music should not be subordinated to other modes of artistic production, 
e.g., the plays of the human voice, the lyrics of a song, or to dance or drama (as in ballet and opera). And in a more complicated way, the drive towards absolute music envisions a music uninterested in musically enacting narratives (as Richard Strauss does in his Death and Transfguration) or representing extramusical contents (as Vivaldi's Four Seasons purports to do). In shedding these latter binds, "absolute music" functions as a contrast term to "program music," music that develops a subject matter (e.g., the story of Don Juan) within its own, musical language (e.g., a symphonic poem). In other words, in trying to distinguish itself from program music, absolute music draws itself outside of the bounds of external reference.

It is as an absolute music, radically liberated from programmatic concerns, that I want to regard the Ur-poem and the dwelling it builds for human beings. Why? Because the "range of vibration" instituted by the Ur-poem neither expresses nor re-presents anything. In fact, we cannot even regard the Ur-poem as a matter of some "content" at play in the language of the poem, for then that language would be articulating what first enables its articulation. In other words, the Ursprache provided by the Ur-poem marks the rim of our being, and is thus part and parcel of the condition of the possibility of reference, not itself referential except in a self-figurative fashion. And it is in these terms that absolute music has been thematized. As Hanslick writes:

Music consists of tonal sequences, tonal forms; these have no other content than themselves. They remind us once again of architecture and dancing, which likewise bring us beautiful relationships without content. However each person may evaluate and name the effect of a piece of music ... its content is nothing but the audible tonal forms; since music speaks not merely by means of tones, it speaks only tones. ${ }^{51}$

And so is the case, I take it, with the Ur-poem and the "range of vibrations" that it "arranges" or einrichtet. About nothing beyond its own coming to be, it does not speak by means of poetic figures, but speaks only poetic figures. As Heidegger writes in the lecture on Andenken: "Die wesentliche Dichtung bezeugt sich zuerst darin, daß ihr Gedichtetes nur im Bereich dieser sich überschwingungden Räume sich hält and aus ihnen spricht," that is: Essential poetry above all bears witness to itself in that what it poetizes only abides and speaks out of the region of those superresonating ranges [which it itself has poetized] (GA 52: 15).

I am trying to develop an analogy between nonreferential tonal ranges and the Ur-poems that key, according to Heidegger, human dwelling. I am doing so given the failure of explanations drawn from Kantian intuitions (Schürmann) and the history of poetics (Warminski). But it is only an analogy. In the end, the language of the poem will have to prove primary, for otherwise this analogy will usurp the originary place of the Ur-poem. Still, I find it a helpful analogy for at least two reasons beyond those already given. First, in any piece, the tonal scale is not somehow determining the piece from a mysterious 
beyond. Instead, it suffuses it. Or we might say that the piece belongs to a tonal abundance such that, at the moment of performance, the piece stands beyond yet remains bound to the scale. This captures, I think, the play of an Ur-poem in human dwelling. It plays over us just as the dichtende Wort over-poetizes the language of the poem. And while we can speak of an Ur-poem as something in itself, a collection of figures, just as we can demarcate tonal scales (e.g., 8-tone and 12-tone scales), at the level of dwelling, the "range of vibration" suffuses our way within the world and upon the earth. A second strength to the analogy is bound to the integral role that silence plays in the deployment of tonal scales. Pieces of music can draw sustenance from the abundance of a tonal scale if and only if they are marked by silence, for tones can resound alongside of one another only when some distance separates their vibrations, only when their vibrations take place in silent spaces. This is crucial, for the Ur-music of the Ur-poem is far from seamless. As we have seen, its ability to call human dwelling to an originary site is predicated upon its ability to expose the silence left in the wake of that monstrous clearing of openness that gathers human beings and Ur-poems alike into the open region of beings. In over-poetizing us as well as the language of the poem, the Ur-poem calls us to the monstrous traces that outline the rim of our being. In other words, poetic dwelling comes into its own in response to an Ur-poem whose absolute music calls us into tonal ranges punctuated by silence.

\section{ABBREVIATIONS}

\section{Cited Works by Martin Heidegger}

BW2 Basic Writings. From "Being and Time" (1927) to "The Task of Thinking" (1964). Ed. David Farrell Krell. 2nd, rev. and expanded ed. San Francisco: Harper San Francisco, 1993.

GA 65 Beiträge Zur Philosophie (Vom Ereignis). Frankfurt am Main: Vittorio Klostermann, 1989.

EHD Erläuterungen zu Hölderlins Dichtung. Frankfurt am Main: Vittotio Klostermann, 1981.

GA 39 Hölderlins Hymnen "Germanien" und "Der Rhein." Frankfurt am Main: Vittorio Klostermann, 1980.

GA 52 Hölderlins Hymne "Andenken." Frankfurt am Main: Vittorio Klostermann, 1982.

GA 53 Hölderlins Hymne "Der Ister." Frankfurt am Main: Vittorio Klostermann, 1984.

DI Hölderlin's Hymn "The Ister." Trans. Willaim McNeill and Julia Davis. Bloomington: Indiana University Press, 1996.

H Holzwege. Frankfurt am Main: Vittorio Klostermann, 1980.

ID Identität und Differenz. Pfullingen: Gunther Neske, 1957.

OWL On the Way to Language. Trans. Peter D. Hertz. New York: Harper \& Row, 1971.

PLT Poetry, Language, Thought. Trans. Albert Hoftstdter. New York: Harper \& Row, 1971. 
PR The Principle of Reason. Trans. Reginald Lilly. Bloomington: Indiana University Press, 1991.

SVG Der Satz vom Grund. Pfullingen: Verlag Günther Neske, 1986.

SZ Sein und Zeit. Tübingen: Max Niemeyer Verlag, 1986.

UzS Unterwegs zur Sprache. Pfullingen: Verlag Günther Neske, 1986.

VA Vortraege und Aufsaetze. Pfullingen: Verlag Günther Neske, 1990.

W Wegmarken. Frankfurt am Main: Vittorio Klostermann, 1978.

WHD Was Heisst Denken? Tübingen: Max Niemeyer Verlag, 1984.

WCT "What Is Called Thinking," in BW2.

\section{NOTES}

1. Dean Young. Strike Anywhere. (Denver: University Press of Colorado. 1995), 16-17.

2. William James. Pragmatism (Cambridge: Harvard University Press, 1978), 95.

3. Rorty's sense of this banality is at play throughout the second volume of his Philosophical Papers, particularly in "Habermas and Lyotard on postmodernity," "Is Derrida a transcendental philosopher?," and "Heidegger, contingency, and pragmatism." See Richard Rorty. Essays on Heidegger and Others: Philosophical Papers Volume 2 (Cambridge: Cambridge University Press, 1991), 164-176, 119-128, and 27-49.

4. Respectively, see: SZ, 226; BT, 269, and $W, 193 ; B W 2,132$. A word about the translations. Unless noted, all translations are my own. If the passage exceeds a sentence or two, the German will be provided. Also, key German terms will be noted parenthetically if the passage is given in English alone. Finally, all citations from Heidegger's texts will be provided within the text and abbreviations employed. A key for the abbreviations lies at the end of this paper.

5. Philip Levine. What Work Is (New York: Alfred A. Knopf, 1992), 38.

6. See similar remarks in "Wozu Dichter?" and "Das Wesen der Sprache" (H, 269; PLT, 95 and UzS, 165-66; OWL, 63).

7. Given economic demands, we cannot consider for whom these poets supposedly write. Such a discussion is an important one and would lead us to interrogate Heidegger's appeal to the Volk when, in the 1930's, he imagined the form a poetically grounded human dwelling would assume. And it would lead us to ask why, in the 1950s, the figure of the Volk replaced the figure of die Sterblichen, "the mortals"? And to what effect, if in fact we are able to ask that question? Another issue we unfortunately will not address concerns whether the measures in question must be provided by poesy in distinction to other literary and nonliterary forms of figuration. This too is an interesting question, but I will have to address it elsewhere.

8. A notable exception to this is Arthur Grugan's "Heidegger: Preparing to Read Hölderlin's Germanien," a study that has proven helpful to me in the course of my research. (See Arthur A. Grugan, "Heidegger Preparing to Read Hölderlin's Germanien," Research in Phenomenology 19 (1989): 139-167.) Also, Fóti, in her reading of the Der Ister course, quite helpfully explores Heidegger's annotative strategy. (See Véronique Fóti. Heidegger and the Poets [Atlantic Highlands, NJ: Humanities Press International Inc., 1992], 44-59), hereafter cited as HAP.

9. One could (and should) pursue this model through all of Heidegger's readings. One would find remarkable similarities from 1934 onwards. Such an account would consume this paper, however, and thus I will draw a few connections in footnotes.

10. As we shall see, this approach to the language of the poem is not unrelated to the belief that poets can provide human existence with a measure. In fact, prior to reading Rilke, Heidegger 
states that "poets in a time of need must poetize, above all, the essence of poetry" $(H, 268$; PLT, 94).

11. When reading Germanien in 1934, Heidegger terms the Grundstimmung the "Machtbereich der Dichtung," the "power-region of the [Hölderlin's] poetry" (GA 39: 139). And when reading Der Rhein, he states that "we seek the inner-core of the poetry, the Grundstimmuing," adding later that "[d]ie entrückende-einrückende und eröffende-überantwortende Grundstimmung stimmt den sagenden Entwurf des Dichters [the enrapturing - engaging and inaugurating — surrendering Grundstim-mung tunes the saying-projection of the poet]" (GA 39: 163 and 223).

12. In the 1942 lecture course on Hölderlin's Andenken, Heidegger writes of Schwingungsräume, "ranges of vibration" that are opened in the play of a poem's own dichtende Wort. Now these ranges, which the dichtende Wort arranges, demarcate the Ort of the poem's saying. "Die wesentliche Dichtung bezeugt sich zuerst darin, daß ihr Gedichtetes nur im Bereich dieser sich überschwingunden Räume sich hält and aus ihnen spricht [Essential poetry above all bears witness to itself in that what it poetizes only abides and speaks out of the region of those super-resonating ranges]" (GA 52: 15). In other words, essential poetry speaks within ranges of its own making, ranges arranged by an Ur-poem. One finds a similar thought in the reading of Germanien and Der Rhein. There Heidegger writes of a Schwingungsgefige, a "resonant fugue" that secures, through the Grundstimmung, the sense of a poem all the way down to its word order. Heidegger writes: "Das Schwingungsgefüge des Sagens ist . . bestimmt durch die Grundstimmung der Dichtung, die sich im inneren Aufriß des ganzen ihre Gestalt verschafft [The resonant fugue of the saying is ... determined through the Grundstimmung of the poetry, which raises itself within the inner outline of the whole of its form]" (GA 39: 15). Later, we will return to these musical overtures in an effort to come to terms with the results of poetic building.

13. As he writes when reading Trakl: "The Ur-poem [Gedicht] of a poet remains unspoken. Neither the individual poems nor the whole says everything. Nevertheless, every poem speaks out of the whole of this Ur-poem, and says the Ur-poem every time. From the site of the Ur-poem rises the wave which, unfailingly, moves the saying as something poetic" $(U z S, 38 ; O W L, 160)$.

14. This is undoubtedly a complex process unto itself, and one would do well to trace it through Heidegger's readings. One would find, I think, a remarkable consistency. For example, when lecturing on Hölderlin's Andenken in 1942, Heidegger writes of a Horchen before Hören that directs a reading through a "venture," a Wagen, which is accompanied by a waiting for the fruits of that venture to arrive (GA 52: 13-14). We haven't time to pursue this further, however.

15. Because my emphasis is upon poetic building, I must leave to the side several issues of interpretation, most notably those raised by Véronique Fóti in her Heidegger and the Poets. There she accuses Heidegger of several interpretive blunders, e.g., "privileging . . . diachronicity over synchronicity," a shortcoming that issues in a "certain disregard for lexis in favor of the event-like singularity and the etymological historicality of the singularized word" (HAP, 36). Also, she objects to what she regards as a totalizing and violent projection of the history of being upon texts that resist the closure such a vision entails (HAP, 111). As I have argued in a review of her study, I find her reading ungenerous to a fault and insufficiently reflexive about her own interpretive commitments, particularly concerning Rilke's work. Nevertheless, she raises important questions to which I cannot do justice here. For the review, see John T. Lysaker, "Heidegger After the Fall," Research in Phenomenology 23 (1993): 201-11.

16. This interplay recalls the interplay between Lichtung and Einrichtung in the Kunstwerkes piece. In discussing how truth comes to pass in the work of art, Heidegger insists that disclosure of beings occurs only within the double event (which shares a single essence) of a Lichtung der Offenheit and an Einrichtung in das Offene, a "clearing of openness" and an "arranging across the open" (H, 48; BW2, 186).

17. A. R. Ammons. Garbage (New York: W. W. Norton and Company, 1993), 13 and 15. Hereafter, 
all cites to the poem will be given in the text using the abbreviation $G$.

18. Rather than tell us that the spindle of energy animating the mound (and all things) is both material and spiritual, Ammons simply invokes both terms, playing them off one another without resolution, leaving us to ask: "but what about the spirit, does it die / in an instant, being nothing in an instant out of / matter, or does it hold on to some measure of / time, not just the eternity in which it is not, / but does death go one being death for a billion / years: this one fact put down is put down / forever, is it, or for forever, forever to be a / part of the changes about it, switches in the / earth's magnetic field, asteroid collisions, / tectonic underplays, to be molten and then not / molten, again and again: when does a fact end" $(G, 37-38)$. This is a remarkable passage, particularly when read alongside Celan's Engführung, for there Celan recoils in horror from a purely vegetative world which addresses us, dead and living, with "a / green / silence, a sepal, an / idea of vegetation attached to it-/green yes, / attached, yes, / under a sneering / sky. / Of, yes, / vegetation" (Paul Gelan, Gesammelte Werke, vol. 1 [Frankfurt am Main: Suhrkamp Verlag. 1983], 200-201). I have modified Michael Hamburger's translation from Poems of Paul Celan (New York: Persea Books, 1988), 143.

19. When the poem asks: "is a poem about garbage garbage / or will this abstract, hollow junk seem beautiful / and necessary as just another offering to the / high assimilations," one must answer yes to both sides of the disjunction $(G, 30)$.

20. The actual history of the "lyric" is vast, long, and riddled with vagueness and ambiguity. I have adopted a definition that captures those pretensions in scope and form that have caught the attention of critics as diverse as de Man and Adorno, while paying heed to the common assumption that lyric poetry concerns the deepest of problems. As Charles Simic writes: "Lyricism, in its truest sense, is the awe before the untranslatable. Like childhood, it is a language that cannot be replaced by any other language. A great lyric poem must approach untranslatability" (Charles Simic. The Unemployed Fortune Teller [Ann Arbor: The University of Michigan Press. 1994], 112). And, in a line that brings the goal of this essay to light: "Both poetry and philosophy, for instance, are concerned with Being. What is a lyric poem, one might say, but the recreation of the experience of Being. In both cases, that need to get down to essentials, to say the unsayable and let the truth of Being shine through" (Charles Simic, Wonderful Words, Silent Truths [Ann Arbor: The University of Michigan Press. 1990], 60).

21. Heidegger offers the same distinction almost twenty years later in the 1951-52 course published as Was Heisst Denken? (WHD, 98; WCT, 152).

22. In the least, even the failure of naming needs to be regarded as a form of naming under erasure, as John Sallis has shown in his "Poetics" (John Sallis, Echoes: After Heidegger Bloomington: Indiana University Press. 1990], 168-189).

23. As I noted earlier, this figural play is what Heidegger tracks when he reads Hölderlin, Rilke, and Trakl: the intersection of their central figures. As Fóti has noted, he tends to overlook the contribution of non-thematic elements to this process, but I think she is wrong to say that he is deaf to autofiguration in the language of the poem (HAP, 36-37). This is, I take it, his primary concern.

24. This echoes an argument from "Das Wesen der Sprache" where Heidegger insists that a language of essence must proceed along and atop the lines of the essence of language $(U z S, 180$ 81; OWL, 94-6).

25. While my interpretation no doubt pushes Heidegger's texts to certain lengths, exploiting certain tendencies at the expense of others, I think my reading carries forward insights at the heart of Heidegger's encounter with poetry, a heart forcefully apparent in "Hölderlin und das Wesen der Dichtung": "Dichtung ist das stiftende Nennen des Seins und des Wesens aller Dinge-kein beliebiges Sagen, sondern jenes, wodurch erst all das ins Offene tritt, was wir dann in der Alltagssprache bereden und verhandeln. Daher nimmt die Dichtung niemals der Sprache als einen vorhandenen Werkstoff auf, sondern die Dichtung selbst ermöglicht erst die Spra- 
che. Dichtung ist die Ursprache eines geschichtlichen Volkes. Also muß ... das Wesen der Sprache aus dem Wesen der Dichtung verstanden werden." My translation reads: "Poetry is the founding naming of being and the essence of all things - not any old saying, but that through which everything, what we discuss and debate in common language, first steps into the open. Therefore poetry never takes up language as some raw material ready at hand, but rather, poetry itself first enables language. Poetry is the originary language [Ursprache] of a historical Volk. Thus... the essence of language must be understood through the essence of poetry" (EHD, 43). But why a Volk? Must human being's dwell in the form of a Volk?

26. The introduction of a response into the work of appraisal recalls the Derrida-Dastur "exchange" in footnote 5 of Of Spirit. There, Derrida reflects upon the ways in which Heidegger's thought might be said to move beyond the privilege of the question (Jacques Derrida, Of Spirit: Heidegger and the Question [Chicago: University of Chicago, 1989], 129-136). Interestingly, Heidegger's readings often find a response to an address at the inception of poetic saying. In the early Hölderlin readings, the coming of the poem is tied to the strike of the divine for which the poet must prepare through, for example, a standhaltende Hören (Leiden), a "forbearing hearing (suffering)" (GA 39, 199-203). Likewise, the Trakl reading takes the language of the poem to unfold only in pursuit of a stranger who has roamed ahead. We should wonder, therefore, whether Heidegger's readings are more sensitive to the play of "response" in the emergence of language than Derrida has allowed.

27. Heidegger argues this in "Die Frage nach der Technik," claiming that the Greeks, and Aristotelian doctrine in particular, "neither knows the cause that is named by this term, nor employs a corresponding Greek name" (VA, 13; BW2, 315).

28. My translation modifies William Lovitt's (BW2, 314).

29. As Heidegger writes at the beginning of the Kunstwerkes piece: "Origin here means that from which and through which a matter [Sache] is what it is and as or how it is. That which something is as or how it is we name its essence [Wesen]. The origin of something is the source or descent [Herkunft] of its essence. The question concerning the origin of the work of art asks after its essential descent [Wesensherkunft]" $(H, 1 ; B W 2,143)$. What concerns us here is the Wesensherkunft, the "essential descent" of the site of human dwelling through the work of Dichten, poetizing.

30. I have often wondered whether Heidegger's conceptual genealogies, in praising Greece and excoriating Rome, do not reintroduce a notion of efficient causality into the history of language? How is it that Roman translations led us so far astray? How can changes in usage determine the meaning of a language? If Rome is responsible for effectively burying the question of being, what does this tell us about the origin or Wesen of language?

31. Heidegger is careful to deny the term's moralistic overtones, and with good reason given our liberal tendency to find in responsibility an agent taking care of those events that $\mathrm{s} /$ he has brought about $(V A, 14 ; B W 2,316)$.

32. This issue is obscured in Hofstadter's translation of "Der Ursprung des Kunstwerkes." At least twice he translates lassen as cause $(H, 31-32 ; B W 2,171-172)$. He does so even though Heidegger explicitly asserts that "the work in no way influences [entwirkt] hitherto existing beings through causal connections [kausale Wirkungszussamhänge]" (H, 58; BW2, 197).

33. It would be interesting to play this thought into Kant's discussion of the first antinomy. One might imagine Heidegger arguing that if reason comes to this antinomy and finds it irreconcilable, this is because it (a) limits causality to efficient causality, and (b) understands the principle of sufficient reason in a way that forgets that reason also needs to be gathered in order to determine the scope of its own sufficiency, and thus it cannot be bounded by the logic of causal laws. But that would be the subject of another paper.

34. Wallace Stevens, The Collected Poems of Wallace Stevens (New York: Alfred A. Knopf, 1954), 160. 35. Reiner Schürmann, Heidegger on Being and Acting: From Principle to Anarchy (Bloomington: Indiana 
University Press, 1987), 160; hereafter cited as $H B A$. While Schürmann's book does not treat the issue of "poetic" categories, one need not stretch very far to imagine his discussion entering into this context.

36. Andrzej Warminski, Readings in Interpretation: Hölderlin, Hegel, Heidegger (Minneapolis: University of Minnesota Press: 1987), lx; Future reference to this work will be included in the text employing the abbreviation RII.

37. This occasionally liberal translation reworks, extensively, the translation found in the revised edition of Basic Writings.

38. I have done little to alter the translation in the revised edition of Heidegger's Basic Writings.

39. A double concealing occurs because the concealment of the clearing of openness is itself concealed as beings come to presence in the open region of disclosure. In "Das Wesen der Wahrheit," Heidegger terms this double concealing das Geheimnis, "the mystery" (W, 191; BW2, 130).

40. Heidegger discusses each of these points at length in his course on Hölderlin's Der Ister, §§ 11-13 (GA 53, 69-91; DI, 55-74). There, he works with the Ungeheure because Hölderlin uses the term to translate $\delta \varepsilon 1 v o ́ v$ in Sophocles's Antigone. Given this rather different context, I will invoke these discussions only generally.

41. In the context of Hölderlin's use of the "monstrous," Heidegger writes of "that which is powerful," das Gewaltige (GA 53, 77; DI, 63).

42. This remark opens the essay "Deformatives." See Reading Heidegger, John Sallis ed. (Bloomington: Indiana University Press, 1993), 29.

43. In reading Der Ister, Heidegger brings these several senses of Ungeheure into the term "Unheimlich," the "uncanny," retaining, for the most part, the issues discussed above. And he is careful to stress that the "uncanniness" of all presencing "entsteht nicht erst zufolge des Menschentums, sondern dieses kommt aus der Unheimlichkeit und bleibt in ihr [does not first arise as a result of humanity; rather, humanity emerges from uncanniness and remains within it]." Moreover, he adds a few lines later: "Noch sind wir gewohnt, das Unheimliche mehr im Sinne eines Eindruckscharackter zu nehmen, statt es als die Grundart des Wesens des Menschen zu denken [We are still used to regarding uncanniness in the sense of an impression rather than thinking about it as the fundamental aspect of the essence of human being]" (GA 53, 88-89; DI, 72-3 - this translation only slightly modifies McNeil's and Davis's.) In other words, Heidegger is concerned to prevent the monstrous from being psychologized. I take his resistance to the language of violence to reflect, in part, that concern.

44. This is not to say, however, that each instance of action, assessement, knowing, and viewing will be discretely scripted by an Ur-poem. Instead, the Ur-poem will institute what we could call "essential figures" that accompany individual disclosures, as the Geviert, "the four-fold," supposedly establishes reference points for that which occurs in between, in das Zwischen. In this regard, I think the Ur-poem does produce something akin to Kant's notion of Sinnlichkeit, "sensibility."

45. As noted earlier, Heidegger, when reading Germanien and Der Rhein, also speaks of a Schwingungsgefige, a "resonant fugue." A product of the Grundstimmung, this "resonant fugue" runs through the whole of the Ur-poem (GA 39: 15).

46. I take both of these translations from Reginald Lilly (PR, 50 and 46).

47. I have retained, for the most part, the translation available in the revised edition of Basic Writings.

48. This may seem at odds with Heidegger's emphasis upon the singular word, particularly in his reading of Andenken. I see matters otherwise, for even while stressing the power of a word like Andenken, Heidegger articulates it alongside of and through other key tropes, e.g., Fest, Schicksal, Traum, etc. In almost every case, in fact, I think Heidegger reads for Grundworte and not for some singular Grundwort.

49. This would be the case even if no Ur-poetry were present, for such is the nature of 
disclosure - a play between a clearing of openness within and through a figurative arrangement of the open region of beings. Thus one might speak of the Ur-music of Ge-stell, and the Schwingungsraum that it institutes: das Bestand, "the standing-reserve."

50. For a thorough discussion of the history of "absolute music," see Carl Dahlhaus, The Idea of Absolute Music (Chicago: The University of Chicago Press, 1989). My discussion draws from this and an earlier work, Carl Dahlhaus, Esthetics of Music (Cambridge: Cambridge University Press), 1982.

51. Eduard Hanslick, On the Musically Beautiful, Indianapolis: Hackett Publishing Company, 1986), 78. 